\title{
The Iberian Massif Landscape and Fluvial Network in Portugal: a geoheritage inventory based on the scientific value
}

\author{
Diamantino Insua Pereira ${ }^{\mathrm{a}, *}$, Paulo Pereira ${ }^{\mathrm{a}}$, José Brilha ${ }^{\mathrm{a}}$, Pedro P. Cunha ${ }^{\mathrm{b}}$ \\ ${ }^{a}$ Institute of Earth Sciences, Pole of the University of Minho, Campus de Gualtar, 4710-057 Braga, Portugal \\ ${ }^{\mathrm{b}}$ IMAR-Marine and Environmental Research Centre, Department of Earth Sciences, University of Coimbra, 3000-272 Coimbra, Portugal
}

\section{A R T I C L E I N F O}

Article history:

Received 24 August 2014

Received in revised form 9 January 2015

Accepted 12 January 2015

Available online 24 February 2015

\section{Keywords:}

Geoheritage

Geoconservation

Inventory

Landscape

Iberian Massif

\begin{abstract}
A B S T R A C T
Integrated in the national inventory of geological heritage in Portugal, the "Iberian Massif Landscape and Fluvial Network" was selected as one of the geological frameworks with international relevance. Taking into account the diversity of geomorphological and stratigraphic elements occurring in the Portuguese Iberian Massif, 38 geosites were selected in order to represent five themes related to the main geomorphological elements of the Iberian Massif Landscape: major residual landforms, granite landforms, tectonic landforms, correlative sediments, and fluvial landforms. For each theme, some subthemes were defined, together with key-areas that were considered for the selection of geosites. A quantitative assessment of the scientific value and vulnerability of all geosites was undertaken using a methodology that numerically scores a set of criteria. Results highlight the Vilariça geosite with toppriority for management based on its high scientific value and high vulnerability, and the key-area of Miranda do Corvo-Lousã Basin because of the high concentration of geosites. The quantitative evaluation shows that seven geosites have high vulnerability and that special attention should be paid to sedimentary sections. These results allow the establishment of priorities for the management of geosites under the scope of a national geoconservation strategy.
\end{abstract}

() 2015 The Geologists' Association. Published by Elsevier Ltd. All rights reserved.

\section{Introduction}

Geoconservation - the conservation of valued geodiversity features through their assessment and management - has strongly increased during the last two decades emerging as a new research area in geosciences (e.g. Ruban, 2010; Henriques et al., 2011; Prosser et al., 2011; Prosser, 2013; Pereira et al., 2013; Silva et al., 2013, 2015; Bradbury, 2014; Brilha, 2015) and an important topic in nature conservation (Brilha, 2002; Gray, 2013). Nature conservation actions are implemented on in situ occurrences of geodiversity elements with high scientific value - geosites. In addition to the scientific value, geosites may also have educational, aesthetic, and cultural value (Brilha, 2015).

Geomorphological features constitute one of the most relevant subjects dealt within the geoconservation movement (Gray, 2001). Geomorphosites are recognised as a special kind of geosites largely owing to their geomorphological relevance, size, dynamics and aesthetics (Bruschi and Cendrero, 2009; Reynard et al., 2009; Pereira and Pereira, 2010).

\footnotetext{
* Corresponding author. Tel.: +351 253604301 .

E-mail addresses: insuad@dct.uminho.pt (D.I. Pereira), paolo@dct.uminho.pt (P. Pereira), jbrilha@dct.uminho.pt (J. Brilha), pcunha@dct.uc.pt (P.P. Cunha).
}

One of the most important topics in geoconservation research has been the development of methodologies focused on geosite assessment. The definition of such guidelines was one of the main objectives of the 'Geomorphosites working group' established in 2001 under the aegis of the International Association of Geomorphologists (Reynard and Coratza, 2013) with different groups of researchers proposing methodological procedures focused on geomorphosite specificities (Bruschi and Cendrero, 2005; Coratza and Giusti, 2005; Pralong, 2005; Serrano and González-Trueba, 2005; Pereira et al., 2007; Reynard et al., 2007; Zouros, 2007; Pereira and Pereira, 2010; Feuillet and Sourp, 2011; Bruschi et al., 2011).

Different regional geomorphological settings and diverse geoconservation goals have not allowed the development of universal guidelines. Nevertheless, it is possible to distinguish two main types of assessments (Bruschi and Cendrero, 2009; Reynard and Coratza, 2013): (1) a qualitative assessment made during the inventory phase characterised by the selection of geomorphosites based on the assessors' knowledge and (2) a numerical assessment as a quantitative approach using predefined criteria in order to compare the inventoried sites. The two approaches must be sequentially considered in a complete geomorphosite assessment. The selection and characterisation of the most valuable geomorphosites can then be followed by a numerical assessment to 
support management decisions such as protection measures or tourism promotion (Pereira and Pereira, 2010).

In spite of the existence of numerous local inventories, the basic background for the implementation of a national geoconservation strategy should be an inventory applied to the whole country with the same methodological approach. The Portuguese inventory of geosites with scientific value was developed during the period 2007-2010, following the methodology proposed by the European Association for the Conservation of the Geological HeritageProGEO (Wimbledon et al., 1999; Brilha et al., 2005, 2008). This approach led to the definition of 27 geological frameworks with international and national relevance and to the identification of about 300 geosites for the whole Portuguese territory. The landscape of the Iberian Massif, the correlative Cretaceous and Cenozoic sedimentary record and the fluvial network constitute geomorphological features of international relevance in Portugal mainland. Therefore, the "Iberian Massif Landscape and Fluvial Network" was selected as one of the frameworks with international relevance in this inventory. A similar framework was previously considered in the Spanish inventory (García-Cortés et al., 2001; García-Cortés, 2008).

Under the scope of this framework, a geosite inventory and quantitative assessment were conducted taking into account the diversity of geomorphological and stratigraphic elements of the Portuguese Iberian Massif (Pereira et al., 2012). The geosites were selected in order to represent 5 themes related with the main geomorphological elements of the Iberian Massif Landscape: (i) Large residual landforms; (ii) Granite landforms; (iii) Tectonic landforms; (iv) Correlative sediments; and (v) Fluvial landforms.

The geomorphological features related with glacial and periglacial dynamics as well as karst and coastal processes were not included in this framework because they constitute specific frameworks under the scope of the Portuguese inventory process (Brilha et al., 2005, 2008) and are addressed elsewhere. Representativeness, scientific use, scientific knowledge, integrity, diversity of features and rarity were criteria used for geosites selection. The vulnerability of geosites was also assessed in order to establish future management priorities.

\section{Geological and geomorphological setting}

The Iberian Massif is the largest morphotectonic unit of Iberia and consists of the basement of Proterozoic and Palaeozoic metamorphic rocks and plutonic rocks (dominated by granites), affected by Variscan and Alpine tectonic deformation (e.g. Matte, 1986; Ribeiro et al., 1990; De Vicente et al., 2011). The Iberian Massif occupies the central and western part of Iberia and covers about $70 \%$ of the Portuguese mainland territory (Fig. 1). The Alpine deformation also generated Mesozoic and Cenozoic basins (Fig. 1). Three major morphotectonic units are considered in mainland Portugal: the Iberian Massif, the Mesozoic basins and the Cenozoic basins (e.g. Wilson et al., 1989; Pais et al., 2012).

The erosion of the Iberian Massif and the consequent infilling of surrounding sedimentary basins created a vast region of low relief during the Late Cretaceous. Due to different basement resistance to weathering, the narrow NW-SE trending Palaeozoic synclines produced quartzite ridges, whereas the large anticlines consisting of slates and metagreywakes developed flat valleys, creating an Appalachian-type relief (Martín-Serrano, 1988).

During the Paleogene and Miocene (until the late Tortonian) a succession of cycles of weathering and erosion continued to develop a vast planation known as Iberian Meseta (e.g. Cunha, 2000). However, the later episodes of denudation were also affected by tectonics and did not produce a perfect planation surface (Ferreira, 1996; Cunha et al., 2000; Cunha and Martins, 2004).

Crossing an extensive area of the Iberian Massif, the Douro and Tejo rivers are the longest Iberian rivers. The geomorphological and sedimentary records of these rivers, as other rivers on the Atlantic western border of Iberia, provide important information about the evolution of the fluvial network, climate and landscape.

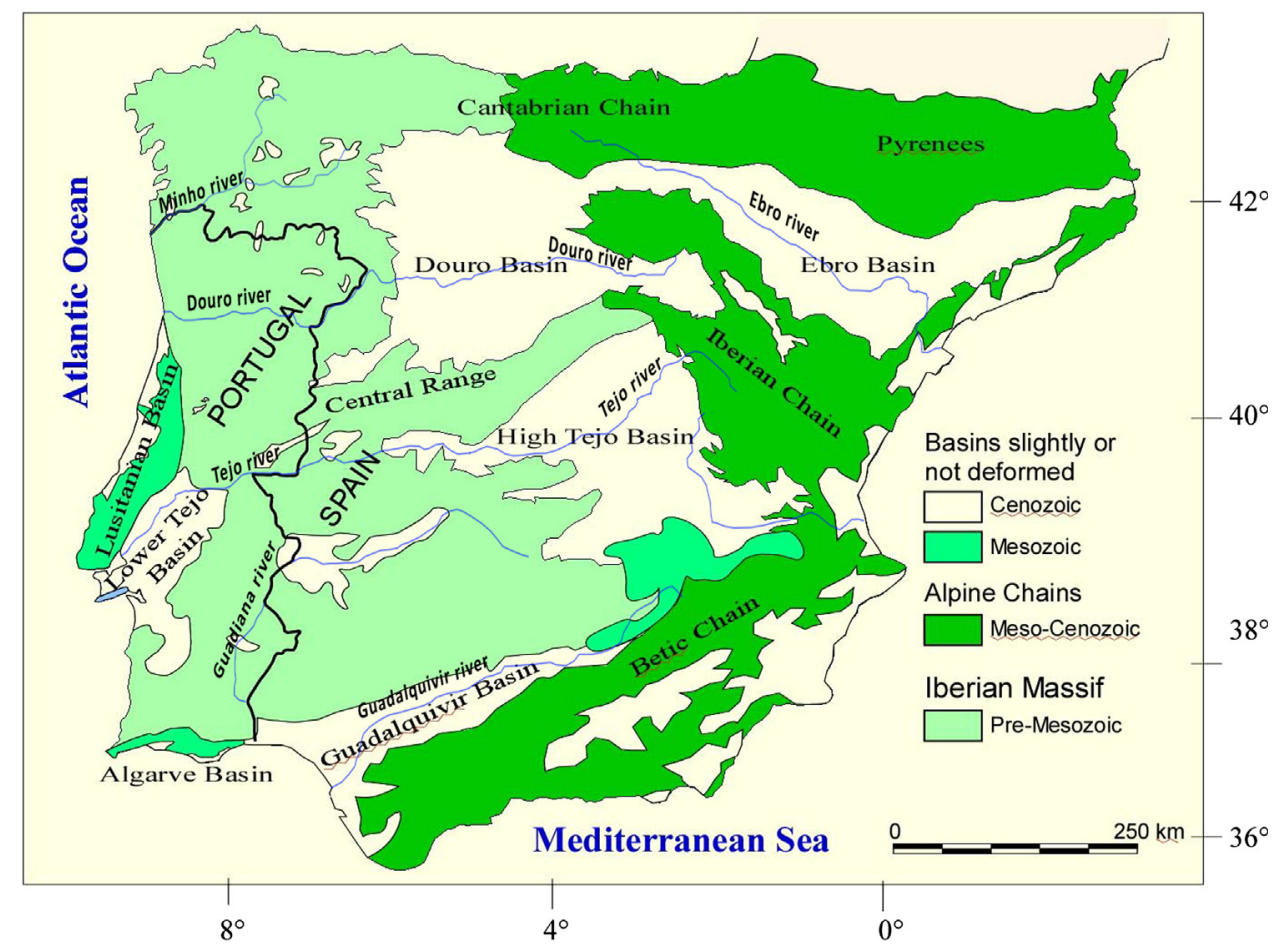

Fig. 1. Major morphotectonic units of Iberia.

Modified from Vera et al. (2004). 
The above-mentioned setting shows that the Iberian Massif has a geomorphological and stratigraphic record that is crucial to understand the different phases of the landscape evolution.

Bordering the Iberian Massif, the Mesozoic Basins are associated with rifting processes and progressive opening of the Atlantic Ocean. Iberia is positioned between the Eurasian and African plates and has been moving eastwards since the Triassic (Wilson et al., 1989). The Lusitanian Basin and the Algarve Basin were opened and filled during the Mesozoic, on the western and southern borders of the Iberian Massif, respectively. The infilling of these Mesozoic basins consists mainly of limestones, marls, sandstones and some evaporites.

At the Late Cretaceous (ca. $80 \mathrm{Ma}$, Campanian) a N-S compressive tectonic regime replaced the Mesozoic extensional tectonic regime, leading to the uplift of the Pyrenees (in the east), and Cantabric cordillera (in the west). At the beginning of Middle Eocene gentle lithosphere folding (Cloetingh et al., 2002; WSWENE trending large synclines, later deformed) led to the development of Cenozoic Basins in Iberia, such as the Lower Tejo and the Mondego basins in Portugal (Pais et al., 2012). Since the Aquitanian, the Betic compression (NW-SE) dominated. Since late Tortonian (ca. 9.5 Ma) the compression climax led to thrusting and to the uplift of important reliefs (e.g. Spanish and Portuguese Central Ranges, Western Mountains) (e.g. Cabral, 1995; De Vicente et al., 2011). During late Tortonian to Zanclean (latest Miocene to Early Pliocene), the sedimentation consisted of endorheic piedmont alluvial fans. However, since the latest Zanclean (ca. 3.6 Ma) the climate changed to be very humid and vast fluvial drainages have developed all over Iberia. Important heterometric deposition (the "Raña deposits"; Ferreira, 1993) led to the enlargement of alluvial fans that became tributaries of exorheic fluvial systems, fan-deltas and deltas, that prograded extensively (coeval high sealevel that reached probably ca. 40-60 m). In a regional context of a low rate of uplift, the change from the generally high sea-levels during the Miocene and Pliocene to the lower ones during the Pleistocene and Holocene have determined the ongoing stage of progressive fluvial incision that probably started at ca. 1.7 Ma ago (Cunha et al., 2012 ).

\section{Geosite inventory}

\subsection{Methodology}

The geological framework "Iberian Massif Landscape and Fluvial Network" is one of the twenty-seven frameworks that were considered under the inventory of the Portuguese geological heritage (Brilha et al., 2008). These frameworks are representative of the whole geological evolution of Portugal and were defined based on the ProGEO methodology (Wimbledon et al., 1999; Brilha et al., 2005, 2008).

Relevant geomorphological features of Portugal were considered in several frameworks. The definition of the framework "Iberian Massif and Landscape Fluvial Network" took into consideration a previous proposal for the inventory of the Portuguese geomorphological heritage, which defined the following themes: residual, granitic, tectonic, fluvial, karst, glacial and periglacial, coastal, and volcanic landforms (Pereira et al., 2006). The first four of these themes, as well as the associated MesoCenozoic sedimentary record are now considered in the scope of the Iberian Massif Landscape and Fluvial Network framework. Features associated with glacial and periglacial geomorphology, as well as karst, coastal and volcanic geomorphology constitute other specific frameworks in the inventory process (Brilha et al., 2005, 2008).

Considering the extensive geographical distribution covered by this framework and the diversity of geomorphological features, the most representative themes and subthemes of the Iberian Massif Landscape and Fluvial Network were defined. Five themes and twenty sub-themes were described in the Portuguese Iberian Massif (Table 1), followed by the selection of geosites representing all these sub-themes. These geosites were selected using qualitative criteria - rarity, representativeness, integrity, diversity, and scientific knowledge - among a list of potential geosites, according with the method proposed by Pereira and Pereira (2010).

The scientific justification of all themes and sub-themes that were selected to represent the geomorphological diversity of the Iberian Massif Landscape and Fluvial Network framework will be presented in the following section.

\subsection{Results}

A total of thirty-seven geosites were selected based on the assessment of their scientific value. According with the type of geosites proposed by Pereira et al. (2007), (19) geosites are of areatype, 12 are point-type and 6 are viewpoint-type (Table 1 ). These geosites are included in the list of national geosites (Brilha et al., 2010) registered by the Portuguese Institute for Nature and Forest Conservation (ICNF), the national agency responsible for nature conservation. Fifteen geosites are located inside protected areas, which guarantee a legal protection under national legislation. Most of the geosites are located in north and central Portugal due to a higher geomorphological diversity and complexity of this sector, in comparison with the southern part of the territory that is dominated by plateaus.

\subsubsection{Large Residual Landforms}

The lithological diversity and the passive influence of tectonic structures produced during the Variscan orogeny had strong implication for the action of erosive agents under the new climatic and tectonic conditions of the Alpine cycle. Therefore, a thick and extensive weathering profile was produced, except over quartzite ridges and some less fractured and unweathered granite areas. Today, the resulting landforms and their tectonic orientation are the best expression of the Variscan orogeny in the relief (Ferreira, 1996; Pereira, 2010). In the Iberian Massif, and particularly in Portugal, three main landforms - plateaus, quartzite crests, and granite inselbergs - have high scientific value (Pereira et al., 2004).

3.2.1.1. Plateaus. The general low relief vast planation surface (Iberian Meseta) developed on the basement of the Iberian Massif is locally displaced by tectonics and represented by plateaus at different elevations. Erosion surfaces are important morphologies in the reconstruction and understanding of landscape evolution on large spatial and temporal scales (Benito-Calvo and PérezGonzález, 2007). Long phases of tectonic stability during the Paleogene and Neogene produced low gradient alluvial systems, resulting in large flattened areas. These low plateaus cut on the basement are well developed in southern and northeastern Portugal, but high plateaus are also represented at the Portuguese Central Range and Western Mountains (Fig. 2).

A plateau landform acquires a higher scientific value when associated with other landscape elements, such as quartzite crests, inselbergs, tectonic reliefs, or river incisions. Due to the extensive geographical dimension of plateaus, no geosite was selected to represent this landform. However, the selection of geosites in crests and inselberg tops took into account the favoured observation conditions of all main elements of the landscape, including plateaus.

3.2.1.2. Quartzite Crests. Quartzite crests arise around 250-300 m above the extensive plateaus of the Iberian Meseta. These crests are exceptional elements of the landscape of mainland Portugal and 
Table 1

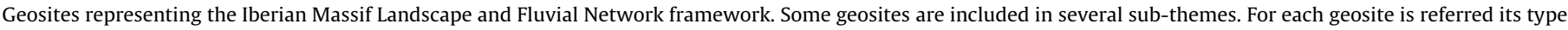
(single point - Sp, area, and viewpoint - Vp) and actual protection status. Sedimentary sections are indicated as single points or inside an area (Vilariça section).

\begin{tabular}{|c|c|c|c|c|}
\hline \multirow[t]{2}{*}{ Theme } & \multirow[t]{2}{*}{ Sub-theme } & \multicolumn{3}{|l|}{ Geosites } \\
\hline & & Name & Type & Protection \\
\hline \multirow{7}{*}{$\begin{array}{l}\text { 1. Large Residual } \\
\text { Landforms }\end{array}$} & 1.1. Plateaus & Geosites 01 to 06 & Vp & \\
\hline & 1.2. Quartzite crests & 01. Marofa crest & Area/Vp & Inside a natural park \\
\hline & & 02. Penedos de Góis crest & Area/Vp & \\
\hline & & 03. Buçaco crest & Area/Vp & Inside a natural park \\
\hline & & 04. Penha Garcia crest & Area/Vp & \\
\hline & & 05. Marvão crest & Area/Vp & \\
\hline & 1.3. Inselbergs & 06. Monsanto inselberg & Area/Vp & \\
\hline \multirow[t]{4}{*}{ 2. Granite landforms } & 2.1. Large-size landforms & 06. Monsanto inselberg & Area/Vp & \\
\hline & 2.2. Medium-size landforms & 07. Penameda bornhardt & Area & Inside a national park \\
\hline & & 08. Rocalva bornhardt & Area & Inside a national park \\
\hline & 2.3. Small-size landforms & 09. Cheira da Noiva landscape & Area & Inside a natural park \\
\hline \multirow[t]{11}{*}{ 3. Tectonic landforms } & 3.1. Pop-up type mountains & Estrela Mountain ${ }^{a}$ & Area & It is a natural park \\
\hline & 3.2. Push-up compressive structures & 10. Bornes (Bornes geodesic site) & Vp & \\
\hline & & 11. Alvão (Minheu geodesic site) & Vp & \\
\hline & 3.3. Strike-slip tectonic basins & 12. Vilariça basin & Area & \\
\hline & & 13. Chaves basin & Area & \\
\hline & & 14. Miranda do Corvo-Lousã basin & Area & \\
\hline & 3.4. Fault scarps & 12. Vilariça scarp & Area & \\
\hline & & 13. Chaves scarp & Area & \\
\hline & & 14. Miranda do Corvo-Lousã scarp & Area & \\
\hline & & 15. Ponsul scarp & $\mathrm{Vp}$ & \\
\hline & 3.5. Fault valleys & 16. Gerês valley & Area & Inside a national park \\
\hline \multirow{6}{*}{$\begin{array}{l}\text { 4. Cretaceous and } \\
\text { Cenozoic sediments }\end{array}$} & 4.1. Cretaceous & 17. Ravina do Picadouro section & Sp/section & \\
\hline & 4.2. Paleogene to Middle Miocene & 18. Nave de Haver section & Sp/section & \\
\hline & & 19. Longroiva section & $\mathrm{Sp} /$ section & \\
\hline & & 20. Monte dos Cancelos section & $\mathrm{Sp} /$ section & \\
\hline & 4.3. Uppermost Miocene to Pliocene & 21. Atenor section & Sp/section & \\
\hline & & 22. Sacões section & Sp/section & \\
\hline \multirow[t]{18}{*}{ 5. Fluvial landforms } & 5.1. Canyons & 23. S. João das Arribas canyon & Vp & Inside a natural park \\
\hline & & 24. Fraga do Puio canyon & $\mathrm{Vp}$ & Inside a natural park \\
\hline & & 25. Poiares syncline/Ribeira do Mosteiro canyon & Area & Inside a natural park \\
\hline & 5.2. Epigenic valleys & 26. Portas do Ródão gorge & Sp & $\begin{array}{l}\text { It is a } \\
\text { natural monument }\end{array}$ \\
\hline & & 27. Senhora da Candosa gorge & Sp & \\
\hline & 5.3. Waterfalls & 28. Fisgas do Ermelo waterfall & Sp & Inside a natural park \\
\hline & & 29. Frecha da Mizarela waterfall & Sp & \\
\hline & & 30. Faia da Água Alta waterfall & Sp & Inside a natural park \\
\hline & & 31. Pulo do Lobo waterfall & Area & Inside a natural park \\
\hline & 5.4. Incised meanders & 12. Douro meander at Vilariça (Vale Meão) & Area & \\
\hline & & 32. Alva meanders & Area & \\
\hline & & 33. Zêzere meanders & Area & \\
\hline & 5.5. Sedimentary terraces & 34. Campos section & Sp/section & \\
\hline & & 35. Cortes section & Sp/section & \\
\hline & & 12. Vilariça section & Area/section & \\
\hline & & 36. Barca d'Alva section & Area & Inside a natural park \\
\hline & & 37. Ródão Terraces section & Area & $\begin{array}{l}\text { Partially inside a } \\
\text { natural monument }\end{array}$ \\
\hline & 5.6. Strath terraces & 31. Pulo do Lobo terrace & Area & Inside a natural park \\
\hline
\end{tabular}

${ }^{\text {a }}$ Representative of a pop-up massif but not considered as a geosite due to its large area (about $900 \mathrm{~km}^{2}$ ).

they are the best morphological expression of an Appalachiantype relief (Fig. 2). The crests' tops represent an older planation surface probably of early Mesozoic age, known as the Initial Surface (Martín-Serrano, 1988, 2004; Pereira, 2010).

Five quartzite ridges were selected as geosites (Table 1, geosites 1-5; Fig. 3a and b). This selection has considered the diversity of geological features visible from viewpoints located on the top of crests, namely: (i) the polygenic plateaus of the Iberian Meseta; (ii) the Initial Surface; and (iii) the river incision on the plateaus (Fig. 2). Taking into account the results of the scientific value assessment, the Penha Garcia crest (geosite 4; Fig. 3a) should be considered a top priority for conservation management.

3.2.1.3. Inselbergs. Occasionally, major granite landforms emerge on the plateaus with their tops often at the same altitude of crests, which represents the remains of the Initial Surface (Martin-Serrano, 1988, 2004; Pereira, 2010).

Monsanto inselberg (geosite 6) was selected as a geosite mainly due to its representativeness and contrast with the surrounding plateau (Fig. 3c). In addition to its scientific value, Monsanto inselberg has also relevant cultural values and is a well-known tourism destination.

\subsubsection{Granite landforms}

In Portugal, granite landforms are typical of temperate climatic zones. Granite landscapes prevail in northern and central Portugal although they are also present in southern areas. These landscapes also contain aspects related with the diversity of mineralogical and geochemical facies, as well as features related to Variscan and Alpine tectonics that have affected extensive granite areas (Pereira, 


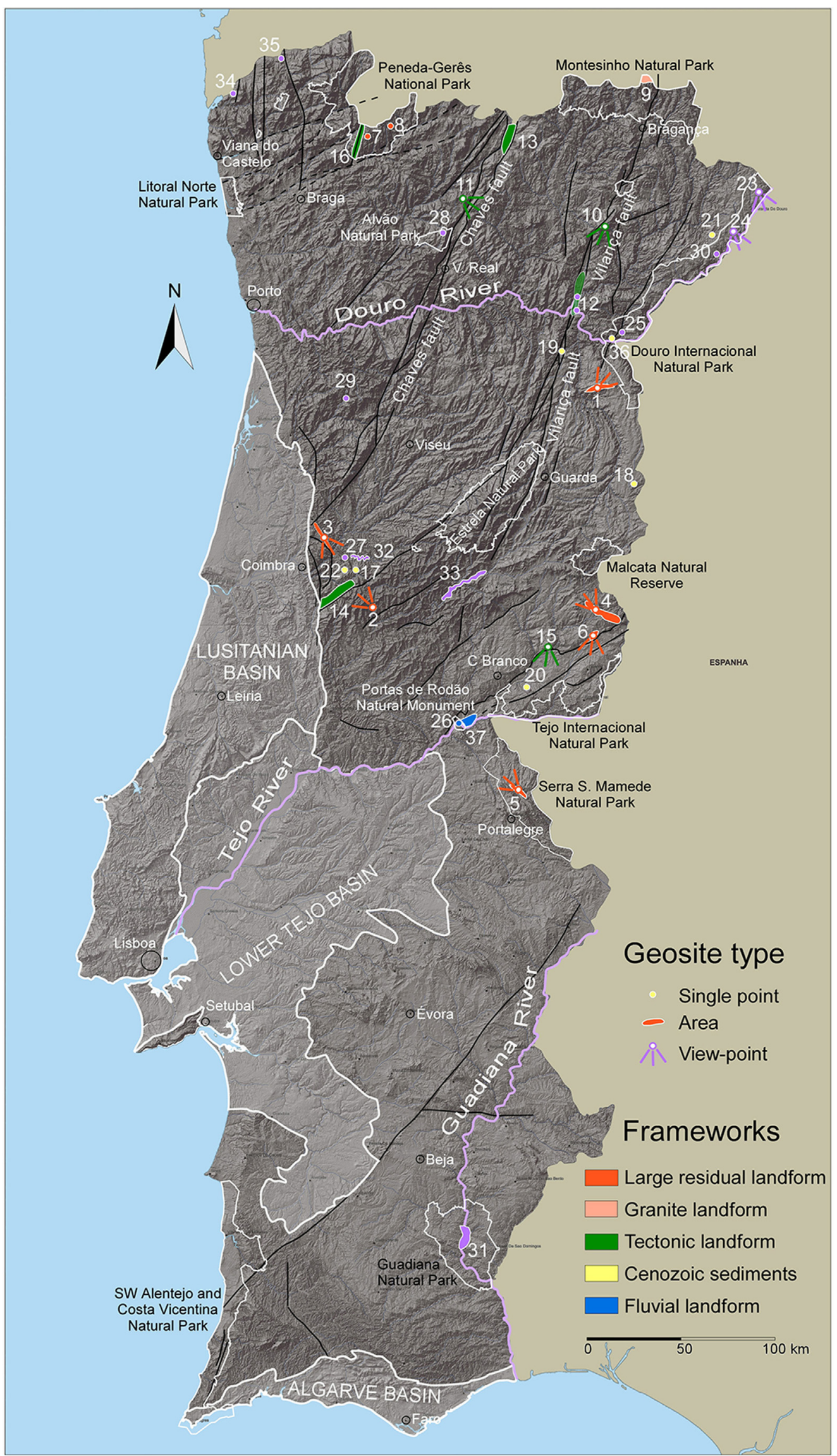

Fig. 2. Geosites and protected areas in the Portuguese Iberian Massif. For each geosite is represented its type and theme. Geosite numbers are referred to Table 1. 

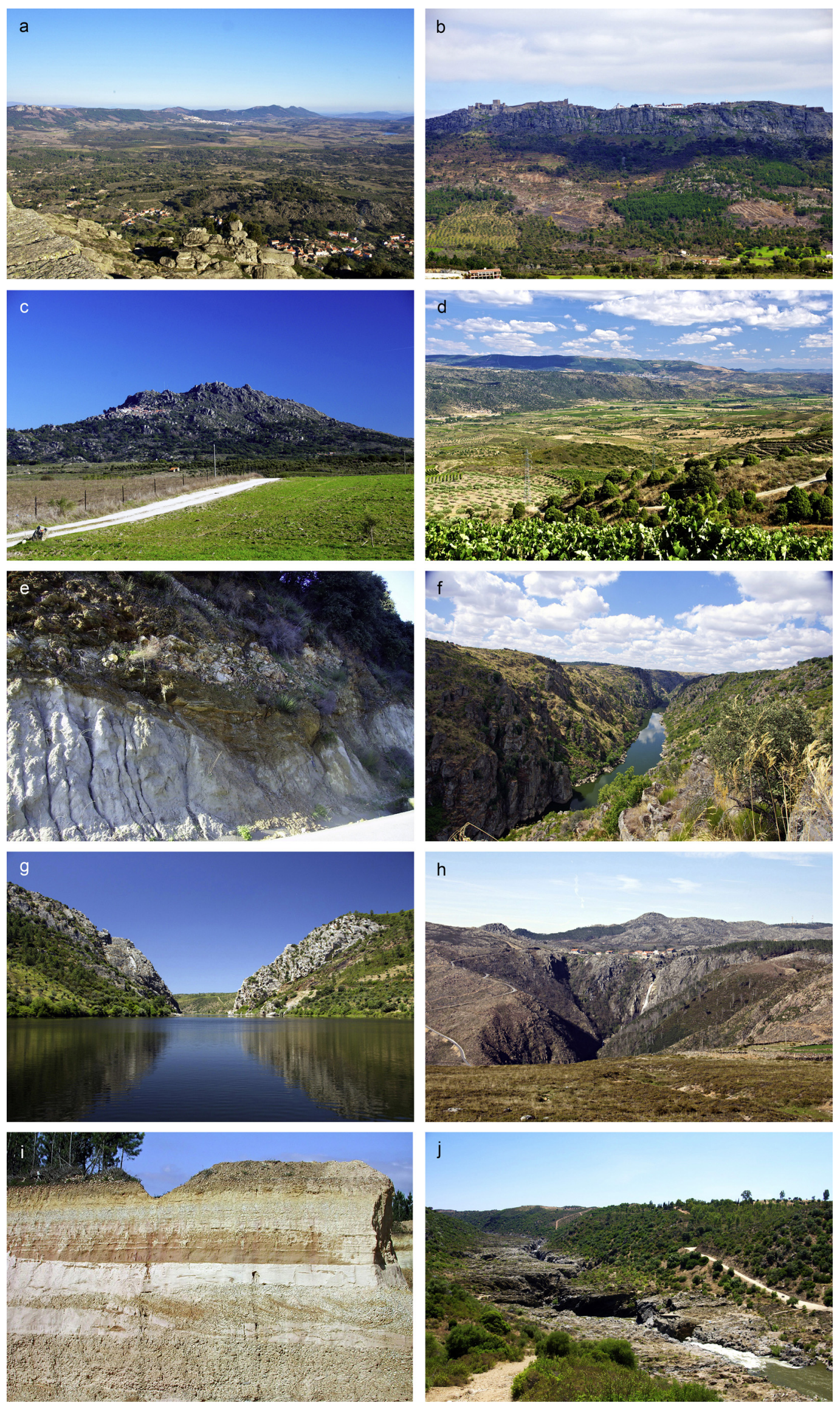

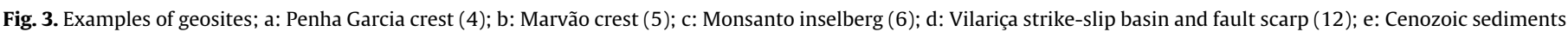
overthrusted by the Cambrian basement in the Longroiva basin (19); f: Douro canyon on S. João das Arribas (23); g: Portas de Ródão epigenic valley (26); h: Frecha da Misarela waterfall (30); i: Minho River terrace in the Campos section (35); j: Pulo do Lobo strath terrace and waterfall in the Guadiana River (32). 
2010). Three sub-themes were defined taking into account the magnitude of landforms.

3.2.2.1. Large granite landforms. Under the scope of this work, isolated landforms with areas around a few tens of square kilometres were considered as large granite landforms. In Portugal, such landforms are mainly represented by inselbergs that were included in the Large Residual Landforms theme.

3.2.2.2. Medium-scale granite landforms. The Peneda-Gerês mountains are characterised by a large diversity of mineralogical and geochemical facies of granitic rocks (Dias et al., 2002), corresponding to different models of granite genesis. The Gerês granite is the dominant lithology occurring within the Peneda-Gerês National Park and is responsible for a characteristic granite landscape. Bornhardts and castle-kopies are the more prominent forms of medium scale and are one of the landmarks of the only Portuguese national park. Based on the criteria listed above, Penameda bornhardt (geosite 7) and Rocalva bornhardt (geosite 8) were selected as geosites representing granite landforms of medium scale (Fig. 2).

3.2.2.3. Small granite landforms. Small granite landforms include geomorphological features with a few square metres of extension, like granite blocks and minor forms in these blocks. This kind of small landform is very characteristic of some granite areas, mainly in mountain areas. In the highest peaks of Montesinho mountain (NE Portugal) the peculiar granite landscape is characterised by small landforms of high relevance. Besides the typical tors and pedestal blocks, an unusual concentration of weathering pits (named as "pias") and pseudobedding is distinctive of this mountain landscape. Due to these specificities, the Cheira da Noiva area (geosite 9) was selected as the most representative geosite of minor granite landforms (Pereira et al., 2007).

\subsubsection{Tectonic landforms}

The compressive intraplate deformation of Iberia that developed since the Campanian caused the differentiation of several morphotectonic blocks controlled by main faults (Cloetingh et al., 2002; De Vicente et al., 2007, 2011). The climax of the tectonic compression, during the late Miocene to Quaternary, was responsible for compressive structures as push-up and strike-slip tectonic basins, bordered by pop-up type mountains, leading to the uplift of the Iberian Massif (De Vicente et al., 2007, 2011).

For the inventory of tectonic landforms, five sub-themes were considered: pop-up type mountains, push-up compressive structures, strike-slip tectonic basins, fault scarps, and fault valleys.

3.2.3.1. Pop-up type mountains. The Western Mountains and the Portuguese Central Range, with a general NE-SW direction, are bounded by NE-SW reverse faults. They are raised edges of areas under compressive intraplate deformation and have been referred to pop-up type mountains (Ribeiro et al., 1990; De Vicente et al., 2007, 2011). In Portugal, the Central Range is bounded by distinct fault scarps and defines a clear boundary between the northern and southern areas of the Iberian Massif, with different rates of uplift and tectonic evolution. Therefore, the Portuguese Central Range is the best example of a pop-up type mountain considering representativeness, key-locality, and other scientific criteria (Table 1).

The Estrela mountain is the higher block of the Portuguese Central Range with a low population density and already protected under Portuguese law as a natural park (Fig. 2). With an area of about $900 \mathrm{~km}^{2}$, Estrela mountain is too large to be considered a single geosite (Pereira et al., 2007) and for this reason its geoconservation strategy should be integrated in the management plan of this protected area.
3.2.3.2. Push-up compressive structures. Two important NNE-SSW strike-slip fault systems known as the Chaves fault and Vilariça fault show very clear features between the Western Mountains and the Portuguese Central Range. With late Cenozoic sinistral movement, these faults gave rise to several push-up compressive structures at both sides of the faults with similar NNE-SSW orientation (Fig. 2). Attending to the scientific and vulnerability criteria, two push-up compressive structures were selected: Bornes mountain (geosite 10) and Alvão mountain (geosite 11).

Bornes mountain borders the Vilariça fault, displaying sharp scarps and establishes a very clear relation with the Vilariça strikeslip basin to the south (Fig. 2). The summit of Bornes mountain was selected as a geosite (10) due to the panoramic view over the surrounding landscape.

Alvão mountain is related with the Chaves fault. The summit on the northern part of the Alvão mountain was selected as a geosite (11) taking in consideration the good observation conditions over the fault scarp, the strike-slip basins to north and south, and the distinctness of plateau steps on the granite basement.

3.2.3.3. Strike-slip tectonic basins. Like the push-up compressive structures, the strike-slip tectonic basins are the most distinct morphological expression of the Chaves and Vilariça faults. These basins have different areas, sediment thickness and stratigraphical records.

The Vilariça basin (geosite 12) is known as the most representative strike-slip basin in Portugal, constituting a keylocality (Fig. 3d). The geological diversity mainly related with tectonic, stratigraphical, and geomorphological features, as well as the existence of a good scientific knowledge (e.g. Pereira and Azevêdo, 1995; Pereira et al., 2000; De Vicente and Vegas, 2009) were also relevant for the selection of this geosite.

In the Chaves basin (geosite 13) the thickness of the sedimentary infilling is remarkable, which could reach $1600 \mathrm{~m}$ according to geophysical data (Baptista, 1998).

The Lousã basin (geosite 14) is noted for its well-known geomorphological and sedimentary record (Daveau et al., 1986; Cunha, 1992) and its peculiar position related with quartzite crests and the NE-SW Lousã fault that limits the Central Range.

3.2.3.4. Fault scarps. The fault scarps that border the Vilariça basin (geosite 12; Fig. 3d), Chaves basin (geosite 13) and Lousã basin (geosite 14) were selected for their representativeness and other criteria already pointed out related with tectonic features. The Ponsul fault scarp in the Idanha-a-Nova geosite (15) was also selected due to its relevance in the proximal sector of the Lower Tejo Cenozoic basin.

3.2.3.5. Fault valleys. Fault valleys are one of the clearest expressions on the landscape of passive Variscan tectonics. The Gerês valley (geosite 16) is a narrow and straight $30 \mathrm{~km}$ long valley. The valley is carved in a NNE-SSW fault cutting the granite massif of the Gerês mountain in the Peneda-Gerês National Park. In addition to the geomorphological expression, several occurrences of thermal spring waters are located along the fault.

\subsubsection{Cretaceous and Cenozoic sediments}

In addition to the main sedimentary infill of the larger Lower Tejo and Mondego Cenozoic basins, several sedimentary remains occur over the Iberian Massif. These comprise Cretaceous and Cenozoic sediments that occur mainly in small late Cenozoic tectonic basins and palaeovalleys carved in the Paleozoic basement. These sediments record tectonic events and characterise several weathering and erosional cycles that are responsible for the multifaceted geomorphology (Cunha, 1992). Three sub-themes integrate six geosites that were selected to represent different allostratigraphic units, ages and basins (geosites 17-22). 
3.2.4.1. Cretaceous sediments. A thick and extensive Cretaceous record (uppermost Aptian to Santonian) is well represented in western central Portugal, reaching inner areas of the Iberian Massif where it covers the basement that suffered a long period of general chemical weathering during the Early to Middle Jurassic and Early Cretaceous, but also onlapping the resistant quartzite ridges. A developed silcrete occurs at the top of this Cretaceous record and represents a period of weathering comprising the uppermost Cretaceous and Palaeogene (Cunha, 1992; Cunha and Pena dos Reis, 1995).

The Ravina do Picadouro geosite (17) was selected due to the succession of sedimentary units ranging in age from the Cretaceous to Miocene, recording several stages of the Iberian Massif morphogenesis.

3.2.4.2. Palaeogene to Upper Miocene sediments. Three geosites document the Palaeogene to late Miocene tectono-sedimentary stages representing different morphotectonic domains in northern and southern areas of the Portuguese Central Range.

In the northeast, the Nave de Haver geosite (18) represents a large alluvial plain in the western border of the Douro Cenozoic Basin. Still in the northeast, the Longroiva geosite (19; Fig. 3e) shows the same unit preserved in a strike-slip basin and contacting by a thrust fault with the basement (Cunha and Pereira, 2000).

South of the Portuguese Central Range, the Monte dos Cancelos geosite (20) shows the Cabeço do Infante Formation, documenting the Paleogene infilling over the vast planation surface cut on the Variscan basement, in a proximal northeast domain of the Lower Tejo Cenozoic Basin.

3.2.4.3. Uppermost Miocene to Pliocene sediments. Sedimentary and geomorphological evidence of the extensive Palaeogene to middle Miocene alluvial plain drainage systems, linking the Iberian Massif to the Atlantic Ocean, is in contrast with the geographically restricted uppermost Miocene-Zanclean alluvial fan sedimentation. This change occurred simultaneously with the beginning of the uplift of the Portuguese Central Range, Western Portuguese Mountains, and other reliefs associated with NNE-SSW strike-slip faults (Cunha, 1992).

Alluvial fan sedimentation culminates with heterometric ochre conglomerates containing large quartzite boulders in proximal areas fed by quartzite relief areas, called rañas in the Portuguese and Spanish Central Range piedmonts. Alluvial fan sedimentation changes laterally into fluvial deposits representing the first evolutionary stage of the present river networks draining to the Atlantic. This actual drainage is considered to be of Piacenzian to Gelagian in age and is predating the progressive fluvial incision that produced the staircases of river terraces (Cunha et al., 1993, 2005, 2012).

Two geosites were selected to represent this stage of the Iberian Massif evolution. In the north, the Atenor geosite (21) shows lithofacies infilling a NW-SE palaeovalley. The sedimentary and geomorphological characteristics provided by this geosite are important for the reconstitution of the drainage network in the proximal western domain of the Douro Cenozoic Basin during the Neogene.

In the Colina de Sacões geosite (22), three allostratigraphic units that comprise the Sacões Group are affected by a thrust that justifies an overlap by the Variscan basement (Lousã fault). These units are correlative of the main uplift events of the Portuguese Central Range.

\subsubsection{Fluvial landforms}

Due to their geomorphological and sedimentary records, rivers provide important archives of Earth history, particularly as indicators of tectonic, climatic and eustatic events recorded in continental areas.
The present river network of the Iberian Massif was influenced by several controls, such as the Alpine tectonics, the resistance of the bedrock, and the late Cenozoic climatic and sea-level evolution. The ongoing stage of river incision has created several features visible at different scales. The international scientific value of the River Douro valley at the Portugal-Spain border is recognised in Spanish and Portuguese geoheritage inventories (Pereira, 2010; García-Cortés, 2008; Pereira et al., 2010) and it is already protected by two natural parks, one in each country. Along a $100 \mathrm{~km}$ stretch, the River Douro has carved a canyon about $600 \mathrm{~m}$ deep on the Iberian Meseta (Antón et al., 2012). The protection of these largescale features can only be achieved under the scope of management plans of both natural parks. The same situation happens in the Tejo and Guadiana valleys (e.g. Santisteban and Schulte, 2007; Martins et al., 2009; Cunha et al., 2012) in central and southern Portugal, respectively. Small-scale fluvial features can be considered as area-type geosites. The most evident features are canyons, epigenic valleys, waterfalls, incised meanders, and strath terraces.

3.2.5.1. Canyons. Two viewpoint-type geosites were selected on the Douro valley as the best sites to observe the canyon-type morphology. The S. João das Arribas geosite (23) provides the best perspective of the deep canyon with almost vertical margins, carved into the granite basement (Fig. 3f). The Fraga do Puio geosite (24) shows the passive influence of fractures in the Variscan basement and the incised meandering pattern of the river course.

The Poiares syncline/Ribeira do Mosteiro geosite (25) was selected in a tributary of the Douro River and shows the fluvial incision on the resistant Palaeozoic quartzites in a syncline structure.

3.2.5.2. Epigenic valleys. In order to document the evolution of long-lived rivers that need to adapt to a new much lower base level through a profound cutting of the basement, three geosites were selected. They are located on the top of quartzite crests for a better panoramic view.

The Portas do Ródão geosite (26) located in the Tejo River (Fig. 3g) was designated in 2009 as a natural monument mainly for its geomorphological relevance (Cunha et al., 2009; Canilho et al., 2010). It is considered the most representative example of this type of valley in Portugal. The association with a diversity of geological and geomorphological features, including erosion surfaces, terraces, and fossils, but also due to the occurrence of important archaeological remains, contribute to the scientific relevance of this geosite (Martins et al., 2009; Cunha et al., 2005, 2009, 2012).

The Senhora da Candosa geosite (27) on the Ceira River epigenic valley is one among several features located near the western limit of the Iberian Massif. This geosite is representative of a fluvial network evolution under a complex tectonic and lithological setting. For the best understanding of its scientific importance, it must be considered together with the nearby geosites: Colina de Sacões sediments, Miranda do Corvo-Lousã basin, and Alva meanders.

3.2.5.3. Waterfalls. Four geosites were selected to represent different types of waterfalls located in the Iberian Massif.

The Fisgas do Ermelo waterfall (geosite 28) is situated in the Alvão Natural Park, at the southern sector of the Alvão mountain, a push-up compressive structure already referred to. This waterfall is caused by a higher resistance of quartzites to the erosion, after the mountain raising (Pereira et al., 2010).

The Frecha da Mizarela waterfall (geosite 29) is the highest waterfall in mainland Portugal and is located on a granite-shale contact in the border of a raised compressive structure (Fig. $3 \mathrm{~h}$ ).

The Faia da Água Alta waterfall (geosite 30) has a special scientific interest due to its proximity to the Douro River and 
denotes the capture of an ancient drainage by the actual Atlantic drainage. The geosite is located in the Douro International Natural Park and is one of the several features that give international relevance to this park.

Finally, Pulo do Lobo waterfall (geosite 31) in southern Portugal is the knick-point on the Guadiana River longitudinal profile, determined by the incision associated to the Last Glacial low sealevel conditions. This waterfall is related with the Pulo do Lobo strath terrace referred below.

3.2.5.4. Incised meanders. The Vale Meão meander located on the southern boundary of the Vilariça basin (geosite 12) was selected due to a clear control of the Douro River course by the Vilariça fault. This large meander is one of the most important features to allow the understanding of the Douro river network evolution in relation to tectonics.

Table 2

Criteria and scores (0-4) for the scientific value assessment of geosites at the national scale.

\begin{tabular}{|c|c|}
\hline \multicolumn{2}{|c|}{ Scientific value } \\
\hline$A$ & Representativeness of geological processes \\
\hline 0 & $\begin{array}{l}\text { Poor example to illustrate elements or processes related with this } \\
\text { geological framework }\end{array}$ \\
\hline 1 & $\begin{array}{l}\text { Reasonable example to illustrate elements or processes related with } \\
\text { this geological framework }\end{array}$ \\
\hline 2 & $\begin{array}{l}\text { Good example to illustrate elements or processes related with this } \\
\text { geological framework }\end{array}$ \\
\hline 4 & $\begin{array}{l}\text { Best example to illustrate elements or processes related with this } \\
\text { geological framework }\end{array}$ \\
\hline$B$ & Key-locality \\
\hline 0 & The geosite is not a reference for this geological framework \\
\hline 1 & The geosite is a national reference for this geological framework \\
\hline 2 & The geosite is an international reference for this geological framework \\
\hline 4 & $\begin{array}{l}\text { The geosite is recognised as a GSSP or ASSP by the IUGS or is a IMA } \\
\text { reference site }\end{array}$ \\
\hline$C$ & Scientific knowledge \\
\hline 0 & $\begin{array}{l}\text { There are abstracts presented in national scientific events about this } \\
\text { geosite, directly related with this geological framework }\end{array}$ \\
\hline 1 & $\begin{array}{l}\text { There are abstracts presented in international scientific events about } \\
\text { this geosite, directly related with this geological framework }\end{array}$ \\
\hline 2 & $\begin{array}{l}\text { There are papers in national scientific publications about this geosite, } \\
\text { directly related with this geological framework }\end{array}$ \\
\hline 4 & $\begin{array}{l}\text { There are papers in international scientific journals about this geosite, } \\
\text { directly related with this geological framework }\end{array}$ \\
\hline$D$ & Integrity \\
\hline 0 & $\begin{array}{l}\text { Geosite with strong preservation problems and with the main geological } \\
\text { elements related with this geological framework very affected }\end{array}$ \\
\hline 1 & $\begin{array}{l}\text { Geosite with preservation problems and with the main geological } \\
\text { elements related with this geological framework quite affected }\end{array}$ \\
\hline 2 & $\begin{array}{l}\text { Geosite not so well preserved but the main geological elements related } \\
\text { with this geological framework are still preserved }\end{array}$ \\
\hline 4 & $\begin{array}{l}\text { The main geological elements related with this geological framework } \\
\text { are very well preserved }\end{array}$ \\
\hline$E$ & Diversity of geological features \\
\hline 0 & Geosite with 1 type of distinct geological features with scientific relevance \\
\hline 1 & $\begin{array}{l}\text { Geosite with } 2 \text { types of distinct geological features with scientific } \\
\text { relevance }\end{array}$ \\
\hline 2 & $\begin{array}{l}\text { Geosite with } 3 \text { types of distinct geological features with scientific } \\
\text { relevance }\end{array}$ \\
\hline 4 & $\begin{array}{l}\text { Geosite with more than } 3 \text { types of distinct geological features with } \\
\text { scientific relevance }\end{array}$ \\
\hline$F$ & Rareness at national level \\
\hline 0 & $\begin{array}{l}\text { There are several examples of geosites representing this geological } \\
\text { framework }\end{array}$ \\
\hline 1 & $\begin{array}{l}\text { There are } 4-5 \text { examples of geosites representing this geological } \\
\text { framework }\end{array}$ \\
\hline 2 & $\begin{array}{l}\text { There are 2-3 examples of geosites representing this geological } \\
\text { framework }\end{array}$ \\
\hline 4 & $\begin{array}{l}\text { The geosite is the only occurrence of this type representing this } \\
\text { geological framework }\end{array}$ \\
\hline
\end{tabular}

The Alva meanders (geosite 32) and Zêzere meanders (geosite 33) are the most representative and are key-localities for incised meanders. These incised meanders are mainly controlled by the uplift of, respectively, the Western Mountains and the Portuguese Central Range, but a large number of meanders have also a lithological and tectonic control (Ribeiro, 1949a,b; Daveau et al., 1986).

3.2.5.5. Fill terraces. Fill terraces are important records for palaeoenvironmental analysis because their sediments are fundamental for the study of climatic and tectonic control of the river network evolution. Expressive terrace staircases occur in the Tejo river valley (and tributaries) over the Cenozoic Lower Tejo Basin, which is beyond the aim of this work. On the Iberian Massif context, five geosites corresponding to terraces with some sedimentary infill were selected.

The Campos section (geosite 34; Fig. 3i) is one of the best terrace staircases in the NE of Iberian Peninsula, with a good relation with coastal terraces. This geosite documents the Plio-Pleistocene fluvial evolution of the Iberian Massif. Sedimentary and geomorphological characteristics, as well as the transition between upper terraces in a tectonic controlled basin are well documented (Vieira et al., 2011; Viveen et al., 2012a,b, 2013).

The Cortes geosite (geosite 35) is a well-exposed, wellpreserved and rare occurrence of a Pleistocene terrace having the sedimentary deposits strongly cemented by silica-rich hydrothermal fluids. The tectonic contact between these Pleistocene sediments and the granite basement is well documented by several faults (Pereira, 1991, 1999).

The already referred Vilariça basin (geosite 12) preserves rare terraces of the Douro River with high scientific relevance. These terraces are being studied under the scope of active tectonics and Quaternary stratigraphy (Cabral et al., 2010; Cunha et al., 2010).

Table 3

Criteria and scores (0-4) for the vulnerability assessment of geosites at the national scale.

Vulnerability

A Fragility of the geological elements

$4 \quad$ Geosite very vulnerable, with possibility of total loss

3 Main features may be damaged

2 Secondary features may be damaged

1 Geosite not vulnerable

B Proximity to potential damaging activities

4 Geosite located less than $50 \mathrm{~m}$ of a potential damaging activity

3 Geosite located less than $200 \mathrm{~m}$ of a potential damaging activity

2 Geosite located less than $500 \mathrm{~m}$ of a potential damaging activity

1 Geosite located more than $500 \mathrm{~m}$ of a potential damaging activity

C Present protection status

$4 \quad$ Geosite without protection and without use restrictions

3 Geosite without protection but with use restrictions

2 Geosite with protection and with use restrictions

1 Geosite with total protection and with strong use restrictions

D Accessibility

$4 \quad$ Geosite located less than $100 \mathrm{~m}$ from a road and bus parking

3 Geosite located less than $100 \mathrm{~m}$ from car access

2 Geosite located less than $100 \mathrm{~m}$ from a 4 wheel-drive access or between 100 and $500 \mathrm{~m}$ from a car access

1 Geosite located more than $100 \mathrm{~m}$ from a 4 wheel-drive access or more than $500 \mathrm{~m}$ from a car access

Population density

4 Geosite located in a municipality with more than 1000 inhabitants $/ \mathrm{km}^{2}$ Geosite located in a municipality with $250-1000$ inhabitants $/ \mathrm{km}^{2}$ Geosite located in a municipality with $100-250$ inhabitants $/ \mathrm{km}^{2}$ Geosite located in a municipality with less than 100 inhabitants $/ \mathrm{km}^{2}$ 
Table 4

Criteria weight used for the geosites assessment of the scientific value and vulnerability (Pereira et al., 2007, 2010).

\begin{tabular}{|c|c|c|c|}
\hline Criteria for scientific value & Weight & Criteria for vulnerability & Weight \\
\hline A. Representativeness & 30 & A. Fragility of the geological elements & 35 \\
\hline B. Key-locality & 20 & B. Proximity to potential damaging activities & 20 \\
\hline C. Scientific knowledge & 10 & C. Present protection status & 20 \\
\hline D. Integrity & 15 & D. Accessibility & 15 \\
\hline E. Geological diversity & 10 & E. Population density & 10 \\
\hline F. Rareness & 15 & & \\
\hline Total & 100 & Total & 100 \\
\hline
\end{tabular}

The Barca de Alva geosite (36) corresponds to a rare terrace sequence of the Douro River, also being currently studied together with those located at Vilariça. Rareness and high vulnerability justified the selection of this geosite.

Finally, Vila Velha de Ródão section (geosite 37) is located upstream of the Portas de Rodão geosite and is one of the best sequences of Tejo river terraces (Martins et al., 2009). Representativeness and scientific knowledge are supported by a good and complete exposure of the terrace staircase (Cunha et al., 2005, 2008, 2012).

3.2.5.6. Strath terraces. The Pulo do Lobo geosite (31) shows a very well preserved and representative strath terrace, located just downstream of the previously referred waterfall (Fig. 3j). This is the best site in Portugal to study the river incision on an ancient river bed produced during the Last Glacial period.

\section{Geosite quantitative assessment}

\subsection{Methodology}

In order to establish priorities for geosite management, a quantitative assessment of the scientific value and vulnerability was made for each geosite of the Portuguese inventory. The criteria used for the assessment of the scientific value were: representativeness, key-locality, scientific knowledge, integrity, diversity of geological features and rarity (Table 2 ). The vulnerability assessment was calculated based in the following criteria: fragility of the geological elements, proximity to potential damaging activities, present protection status, accessibility, and population density (Table 3). The weight of each criterion for the scientific value and vulnerability assessment is indicated in Table 4 (modified from Pereira et al., 2007, 2010).

Table 5

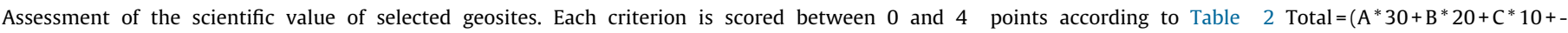
$\left.\mathrm{D}^{*} 15+\mathrm{E} * 10+\mathrm{F}^{*} 15\right) / 4$.

\begin{tabular}{|c|c|c|c|c|c|c|c|c|c|}
\hline \multicolumn{2}{|c|}{ Geosite } & \multicolumn{6}{|c|}{ Criteria } & \multicolumn{2}{|c|}{ Scientific value } \\
\hline No. & Name & A & $\mathrm{B}$ & $\mathrm{C}$ & $\mathrm{D}$ & E & $\mathrm{F}$ & Total & Rank \\
\hline 12 & Vilariça basin/scarp & 4 & 2 & 2 & 2 & 2 & 1 & 61.25 & 1 \\
\hline 31 & Pulo do Lobo waterfall/terrace & 4 & 1 & 1 & 4 & 2 & 1 & 61.25 & 1 \\
\hline 29 & Frecha da Mizarela waterfall & 4 & 1 & 1 & 4 & 1 & 1 & 58.75 & 3 \\
\hline 24 & Fraga do Puio canyon & 4 & 1 & 1 & 4 & 0 & 1 & 56.25 & 4 \\
\hline 04 & Penha Garcia crest & 4 & 1 & 2 & 2 & 2 & 0 & 52.50 & 5 \\
\hline 25 & Poiares syncline/Ribeira do Mosteiro canyon & 4 & 1 & 1 & 2 & 2 & 0 & 50.00 & 6 \\
\hline 06 & Monsanto inselberg & 4 & 1 & 1 & 2 & 0 & 1 & 48.75 & 7 \\
\hline 19 & Longroiva section & 2 & 1 & 2 & 2 & 2 & 1 & 41.25 & 8 \\
\hline 23 & S. João das Arribas canyon & 2 & 1 & 1 & 4 & 0 & 1 & 41.25 & 8 \\
\hline 08 & Rocalva bornhardt & 2 & 1 & 2 & 4 & 0 & 0 & 40.00 & 10 \\
\hline 28 & Fisgas do Ermelo waterfall & 2 & 1 & 2 & 4 & 0 & 0 & 40.00 & 10 \\
\hline 37 & Ródão terraces & 2 & 1 & 4 & 2 & 1 & 0 & 40.00 & 10 \\
\hline 07 & Penameda bornhardt & 2 & 1 & 1 & 4 & 0 & 0 & 37.50 & 13 \\
\hline 10 & vg Bornes & 2 & 1 & 1 & 4 & 0 & 0 & 37.50 & 13 \\
\hline 26 & Portas do Ródão gorge & 2 & 1 & 2 & 2 & 2 & 0 & 37.50 & 13 \\
\hline 30 & Faia da Água Alta canyon & 2 & 1 & 1 & 4 & 0 & 0 & 37.50 & 13 \\
\hline 13 & Chaves basin/scarp & 2 & 1 & 1 & 2 & 2 & 0 & 35.00 & 17 \\
\hline 14 & Miranda do Corvo-Lousã basin/scarp & 2 & 1 & 1 & 2 & 2 & 0 & 35.00 & 17 \\
\hline 34 & Campos section & 2 & 1 & 2 & 2 & 1 & 0 & 35.00 & 17 \\
\hline 35 & Cortes section & 2 & 1 & 2 & 2 & 1 & 0 & 35.00 & 17 \\
\hline 18 & Nave de Haver section & 2 & 1 & 1 & 2 & 0 & 1 & 33.75 & 21 \\
\hline 02 & Penedos de Góis crest & 2 & 1 & 1 & 2 & 1 & 0 & 32.50 & 22 \\
\hline 03 & Buçaco crest & 2 & 1 & 1 & 2 & 1 & 0 & 32.50 & 22 \\
\hline 09 & Cheira da Noiva area & 1 & 1 & 2 & 4 & 0 & 0 & 32.50 & 22 \\
\hline 22 & Sacões section & 2 & 1 & 2 & 2 & 0 & 0 & 32.50 & 22 \\
\hline 36 & Barca d'Alva section & 2 & 1 & 1 & 2 & 1 & 0 & 32.50 & 22 \\
\hline 05 & Marvão crest & 2 & 1 & 1 & 2 & 1 & 0 & 32.50 & 27 \\
\hline 01 & Marofa crest & 2 & 1 & 1 & 2 & 1 & 0 & 32.50 & 28 \\
\hline 11 & Alvão (vg Minheu) & 2 & 1 & 1 & 2 & 0 & 0 & 30.00 & 28 \\
\hline 16 & Gerês valley & 2 & 1 & 1 & 2 & 0 & 0 & 30.00 & 28 \\
\hline 17 & Ceira section & 2 & 1 & 1 & 2 & 0 & 0 & 30.00 & 28 \\
\hline 20 & Monte dos Cancelos section & 2 & 1 & 1 & 2 & 0 & 0 & 30.00 & 28 \\
\hline 21 & Atenor section & 2 & 1 & 1 & 2 & 0 & 0 & 30.00 & 28 \\
\hline 27 & Senhora da Candosa gorge & 2 & 1 & 1 & 2 & 0 & 0 & 30.00 & 28 \\
\hline 32 & Alva meanders & 2 & 1 & 1 & 2 & 0 & 0 & 30.00 & 28 \\
\hline 33 & Zêzere meanders & 2 & 1 & 1 & 2 & 0 & 0 & 30.00 & 28 \\
\hline 15 & Ponsul scarp & 1 & 1 & 1 & 2 & 0 & 0 & 22.50 & 37 \\
\hline
\end{tabular}




\subsection{Results}

The results of the quantitative assessment of geosites representing the Iberian Massif Landscape and Fluvial Network framework are presented in Tables 5 and 6. Concerning the scientific value (Table 5), the following geosites should be pointed out:

- Vilariça tectonic basin and scarp, an area that includes the Vale Meão meander, as one of the most important geosites;

- Pulo do Lobo waterfall, including the strath terraces, also a topvalue geosite;

- Mizarela waterfall, that stresses the tectonic and lithological controls of waterfalls;

- Fraga do Puio canyon, a viewpoint over the Douro River and the Poiares syncline/Ribeira do Mosteiro canyon, an area that comprehends several geological features;

- Penha Garcia crest and Monsanto inselberg, both representing the residual landforms theme;

- Longroiva section, showing the Paleogene-Miocene sediments thrust by the Paleozoic basement in a strike-slip basin;

- Rocalva bornhardt, as a granite landform.

Regarding the results of the geosites vulnerability assessment (Table 6), seven geosites are assessed with high vulnerability. Among these seven geosites there are two in the top 10 for the scientific value: Vilariça basin and scarp and the Longroiva section.
The conjugation of a high scientific value with a high vulnerability justifies a top priority in the implementation of management strategies for both geosites.

\section{Discussion}

The obtained results allow us to make some observations on the methodology used for undertaking inventories and assessment of geosites.

Firstly, the selection of geosites using geomorphological themes and sub-themes constitutes a good procedure to guarantee a systematic inventory of geomorphosites based on their scientific significance. However, this type of selection requires a previous good scientific knowledge of the geomorphological evolution of the territory. The collaboration of the national geomorphological community is considered an advantage in order to cover all the relevant geomorphological features.

Secondly, the quantitative assessment of the scientific value and vulnerability is an important tool to support decision-making regarding nature conservation strategies. This quantification helps to realise the strengths and weaknesses of each geosite and also to establish priorities for the implementation of conservation actions.

Thirdly, it should be stressed that the quantification assessment is made after the conclusion of the geosites selection procedure. This means that all geosites in the inventory have been selected for their high scientific importance at the national level. If a certain geosite is ranked with a low score for the scientific value, this does

Table 6

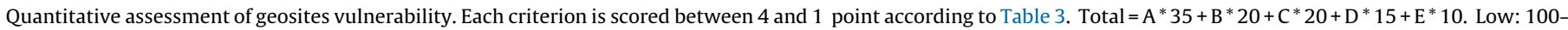
200; Moderate: 201-300; High: 301-400. SV: ranking of scientific value.

\begin{tabular}{|c|c|c|c|c|c|c|c|c|c|}
\hline \multicolumn{3}{|c|}{ Geosite } & \multicolumn{5}{|c|}{ Criteria } & \multicolumn{2}{|c|}{ Vulnerability } \\
\hline No. & Name & SV & A & B & $\mathrm{C}$ & $\mathrm{D}$ & $E$ & Total & Rank \\
\hline 34 & Campos section & 17 & 4 & 4 & 4 & 4 & 3 & 390 & High \\
\hline 12 & Vilariça basin/scarp & 1 & 4 & 4 & 4 & 4 & 1 & 370 & High \\
\hline 19 & Longroiva section & 8 & 4 & 4 & 4 & 4 & 1 & 370 & High \\
\hline 21 & Atenor section & 28 & 4 & 4 & 4 & 4 & 1 & 370 & High \\
\hline 13 & Chaves basin/scarp & 17 & 3 & 4 & 4 & 4 & 2 & 345 & High \\
\hline 35 & Cortes section & 17 & 3 & 4 & 4 & 4 & 2 & 345 & High \\
\hline 18 & Nave de Haver section & 21 & 4 & 4 & 3 & 2 & 1 & 320 & High \\
\hline 36 & Barca d'Alva section & 22 & 3 & 4 & 2 & 4 & 1 & 295 & Moderate \\
\hline 22 & Sacões section & 22 & 2 & 3 & 4 & 4 & 1 & 280 & Moderate \\
\hline 02 & Penedos de Góis crest & 22 & 2 & 1 & 4 & 4 & 2 & 250 & Moderate \\
\hline 03 & S. Pedro Dias crest & 22 & 2 & 1 & 4 & 4 & 2 & 250 & Moderate \\
\hline 14 & Lousã basin/scarp & 17 & 2 & 1 & 4 & 4 & 2 & 250 & Moderate \\
\hline 01 & Marofa crest & 28 & 2 & 1 & 4 & 4 & 1 & 240 & Moderate \\
\hline 04 & Penha Garcia crest & 5 & 2 & 1 & 4 & 4 & 1 & 240 & Moderate \\
\hline 05 & Marvão crest & 27 & 2 & 1 & 4 & 4 & 1 & 240 & Moderate \\
\hline 06 & Monsanto inselberg & 7 & 2 & 1 & 4 & 4 & 1 & 240 & Moderate \\
\hline 17 & Ceira section & 28 & 2 & 1 & 4 & 4 & 1 & 240 & Moderate \\
\hline 20 & Monte dos Cancelos section & 28 & 2 & 1 & 4 & 4 & 1 & 240 & Moderate \\
\hline 25 & Ribeira do Mosteiro canyon & 6 & 2 & 1 & 4 & 4 & 1 & 240 & Moderate \\
\hline 27 & Sra da Candosa gorge & 28 & 2 & 1 & 4 & 4 & 1 & 240 & Moderate \\
\hline 32 & Alva meanders & 28 & 2 & 1 & 4 & 4 & 1 & 240 & Moderate \\
\hline 33 & Zêzere meanders & 28 & 2 & 1 & 4 & 4 & 1 & 240 & Moderate \\
\hline 37 & Ródão terraces & 10 & 3 & 2 & 2 & 2 & 1 & 225 & Moderate \\
\hline 29 & Frecha da Mizarela waterfall & 3 & 2 & 1 & 4 & 2 & 2 & 220 & Moderate \\
\hline 15 & Ponsul scarp & 37 & 2 & 1 & 4 & 2 & 1 & 210 & Moderate \\
\hline 10 & Bornes (vg Bornes) & 13 & 1 & 1 & 4 & 4 & 1 & 205 & Moderate \\
\hline 23 & S. João das Arribas, canyon & 8 & 2 & 1 & 2 & 4 & 1 & 200 & Low \\
\hline 26 & Portas do Ródão gorge & 13 & 2 & 1 & 2 & 4 & 1 & 200 & Low \\
\hline 11 & Alvão (vg Minheu) & 28 & 1 & 1 & 4 & 2 & 1 & 175 & Low \\
\hline 31 & Pulo do Lobo waterfall/terrace & 1 & 2 & 1 & 2 & 2 & 1 & 170 & Low \\
\hline 09 & Cheira da Noiva area & 22 & 2 & 1 & 2 & 1 & 1 & 155 & Low \\
\hline 24 & Fraga do Puio canyon & 4 & 2 & 1 & 2 & 1 & 1 & 155 & Low \\
\hline 28 & Fisgas do Ermelo waterfall & 10 & 2 & 1 & 2 & 1 & 1 & 155 & Low \\
\hline 30 & Faia da Água Alta waterfall & 13 & 2 & 1 & 2 & 1 & 1 & 155 & Low \\
\hline 16 & Gerês valley & 28 & 1 & 1 & 2 & 3 & 1 & 150 & Low \\
\hline 07 & Penameda bornhardt & 13 & 1 & 1 & 2 & 1 & 1 & 120 & Low \\
\hline 08 & Rocalva bornhardt & 10 & 1 & 1 & 2 & 1 & 1 & 120 & Low \\
\hline
\end{tabular}


not mean that it should be removed from the inventory due to a lack of scientific relevance, it just means that its scientific value is relatively lower in comparison with other geosites. The numerical assessment gives relative results and not absolute ones as all assessed geosites were already previously selected taking into account rigorous qualitative criteria.

The quantitative assessment procedure intends to obtain the best discrimination possible between geosites. This discrimination is also enhanced by the fact that the higher score for each criterion is 4 , followed by 2 and not by 3 . For the evaluation of the scientific value, rarity and key-locality are the two determinant criteria responsible for the difficulty to obtain final scores higher than 50. Achieving scientific values higher than 60 is only possible where geosites have international relevance and scores higher than 80 are only possible for global top-class geosites.

Two geosites have obtained final scores higher than 60, clearly denoting their international relevance (Table 5). Mainly due to "integrity" and "diversity of geological features" criteria, five geosites have scores between 58.75 and 48.75, which reflects the fact that these geosites are the best examples of elements or processes related to the geological framework "Iberian Massif Landscape and Fluvial Network". Geosites with scores close to 40 are not unique or rare but are geosites with good representativeness, integrity or with solid scientific knowledge. Finally, 9 geosites have obtained scores equal or lower than 30. Generally, these geosites have just one geological feature related to the framework but still they are amongst the more relevant in the country for representing the Iberian Massif Landscape and Fluvial Network.

\section{Conclusions}

Based on the ProGEO methodology, the Portuguese geoheritage inventory was defined on 27 geological frameworks represented by 320 geosites of national and international scientific value. One of these frameworks, the Iberian Massif Landscape and Fluvial Network, concerns exclusively geomorphological features of the Iberian Massif. The Iberian Massif is the largest morphotectonic unit of Iberia, characterised by a diverse landscape that is related to the diversity of lithology, tectonic structures, palaeoclimates and geological processes, among others. The extension and diversity of landforms of the Iberian Massif justifies the definition of themes and subthemes for the selection of geosites representing the Iberian Massif Landscape and Fluvial Network framework.

Thirty-eight geosites with scientific value of international or national relevance were selected based on criteria, such as: representativeness, integrity, rarity, and scientific knowledge. The inventory of geosites was based on the definition of themes, reproduced at different scales. For instance, waterfalls are a subtheme of Fluvial Landforms, one of the themes for the Iberian Massif Landscape and Fluvial Network framework. The obtained results show that this methodology, supported by objective criteria, ensures the representation of most of the scientific features under the scope of this framework. We assume that this inventory methodology can be applied to other types of geoheritage.

The inventory highlighted that several geosites are concentrated in key-areas, particularly in the Miranda do Corvo-Lousã basin and nearby areas. This fact may support a future strategy of protection based on the designation of these areas as protected areas, based on their geological interest and in accordance with Portuguese law.

The quantitative assessment of the scientific value and vulnerability of geosites is an important tool in developing the national geoconservation strategy. The results of the assessment made on the 38 geosites show that 7 geosites have high vulnerability and that special attention should be paid to sedimentary sections. Furthermore, the Vilariça geosite is a toppriority for management due to its high scientific value and high vulnerability. The results of the national geoheritage inventory have already been given to the National Institute of Conservation of Nature and Forests, the institutional authority responsible for the protection and management of the Portuguese natural heritage.

\section{Acknowledgments}

This paper results of the research done at the University of Minho and at the Geology Centre of the University of Porto, both partially founded by the Foundation for Science and Technology (strategic project with reference PEst-OE/CTE/UI0039/2014), and IMAR-CMA - University of Coimbra, sponsored by the Foundation for Science and Technology (Portugal).

\section{References}

Antón, L.R., Rodés, A., De Vicente, G., Pallàs, R., Garcia-Castellanos, D., Stuart, F.M., Braucher, R., Bourlès, D., 2012. Quantification of fluvial incision in the Duero Basin (NW Iberia) from longitudinal profile analysis and terrestrial cosmogenic nuclide concentrations. Geomorphology 165-166, 50-61, http://dx.doi.org/ 10.1016/j.geomorph.2011.12.036.

Baptista, J.C., 1998. Estudo neotectónico da zona de falha Penacova-Régua-Verin. $\mathrm{PhD}$ thesis, Univ. Trás-os-Montes e Alto Douro.

Benito-Calvo, A., Pérez-González, A., 2007. Erosion surfaces and Neogene landscape evolution in the NE Duero Basin (north-central Spain). Geomorphology 88, 226-241, http://dx.doi.org/10.1016/j.geomorph.2006.11.005.

Bradbury, J., 2014. A keyed classification of natural geodiversity for land management and nature conservation purposes. Proceedings of the Geologists' Association 125, 329-349, http://dx.doi.org/10.1016/j.pgeola.2014.03.006.

Brilha, J., 2002. Geoconservation and protected areas. Environmental Conservation 29, 273-276, http://dx.doi.org/10.1017/S0376892902000188.

Brilha, J., 2015. Inventory and quantitative assessment of geosites and geodiversity sites: a review. Geoheritage, http://dx.doi.org/10.1007/s12371-014-0139-3.

Brilha, J., Alcala, L., Almeida, A., Araújo, A., Azerêdo, A., Azevedo, M.R., Barriga, F., Brum da Silveira, A., Cabral, J., Cachão, M., Caetano, P., Cobos, A., Coke, C., Couto, H., Crispim, J., Cunha, P.P., Dias, R., Duarte, L.V., Dória, A., Falé, P., Ferreira, N., Ferreira Soares, A., Fonseca, P., Galopim de Carvalho, A., Gonçalves, R., Granja, H., Henriques, M.H., Kullberg, J.C., Kullberg, M.C., Legoinha, P., Lima, A., Lima, E., Lopes, L., Madeira, J., Marques, J.F., Martins, A., Martins, R., Matos, J., Medina, J., Miranda, R., Monteiro, C., Moreira, M., Moura, D., Neto de Carvalho, C., Noronha, F., Nunes, J.C., Oliveira, J.T., Pais, J., Pena dos Reis, R., Pereira, D., Pereira, P., Pereira, Z., Piçarra, J., Pimentel, N., Pinto de Jesus, A., Prada, S., Prego, A., Ramalho, L., Ramalho, M., Ramalho, R., Relvas, J., Ribeiro, A., Ribeiro, M.A., Rocha, R., Sá, A. Santos, V., Sant'ovaia, H., Sequeira, A., Sousa, M., Terrinha, P., Valle Aguado, B., Vaz, N., 2010. O inventário nacional do património geológico: abordagem metodológica e resultados. e-Terra 18, 4.

Brilha, J., Andrade, C., Azerêdo, A., Barriga, F., Cachão, M., Couto, H., Cunha, P.P., Crispim, J.A., Dantas, P., Duarte, L.V., Freitas, M.C., Granja, M.H., Henriques, M.H., Henriques, P., Lopes, L., Madeira, J., Matos, J., Noronha, F., Pais, J., Piçarra, J., Ramalho, M., Relvas, J., Ribeiro, A., Santos, A., Santos, V., Terrinha, P., 2005. Definition of the Portuguese frameworks with international relevance as an input for the European geological heritage characterisation. Episodes 28, 177-186.

Brilha, J., Barriga, F., Cachão, M., Couto, H., Dias, R., Henriques, M.H., Kullberg, J.C., Medina, J., Moura, D., Nunes, J.C., Pereira, D., Pereira, P., Prada, S., Sá, A., 2008. Geological heritage inventory in Portugal: implementing geological frameworks. In: 5th International Symposium ProGEO on the Conservation of the Geological Heritage Abstracts, Rab, Croatia, October 1-5, p. 93.

Bruschi, V., Cendrero, A., 2005. Geosite evaluation: can we measure intangible values? II Quaternario 18, 293-306

Bruschi, V., Cendrero, A., 2009. Direct and parametric methods for the assessment of geosites and geomorphosites. In: Reynard, E., Coratza, P., Regolini-Bissig, G. (Eds.), Geomorphosites. Pfeil, Munchen, pp. 73-88.

Bruschi, V., Cendrero, A., Cuesta, J., 2011. A statistical approach to the validation and optimisation of geoheritage assessment procedures. Geoheritage 3, 131-149, http://dx.doi.org/10.1007/s12371-011-0038-9.

Cabral, J., 1995. Neotectónica em Portugal Continental. Mem. Inst. Geol. e Min. 31, Lisboa.

Cabral, J., Perea, H., Figueiredo, P.M., Besana-Ostman, G.M., Silveira, A.B., Cunha, P.P., Gomes, A., Lopes, F.C., Pereira, D., Rockwell, T., 2010. Preliminary results of a paleoseismological study of the Vilariça fault (NE Portugal). In: Resúmenes de la $1^{\mathrm{a}}$ Reunión Ibérica sobre Fallas Activas y Paleosismología, Sigüenza, España, pp. $41-44$

Canilho, S., Cunha, P.P., Pereira, D., 2010. Geodiversidade no Monumento Natural das Portas de Ródão. e-Terra 18 (14), 4., http://e-terra.geopor.pt.

Cloetingh, S., Burov, E., Beekman, F., Andeweg, B., Andriessen, P.A.M., GarciaCastellanos, D., De Vicente, G., Vegas, R., 2002. Lithospheric folding in Iberia. Tectonics 21, 1041-1067, http://dx.doi.org/10.1029/2001TC901031. 
Coratza, P., Giusti, C., 2005. Methodological proposal for the assessment of the scientific quality of geomorphosites. II Quaternario 18, 307-313.

Cunha, P.P., 1992. Estratigrafia e sedimentologia dos depósitos do Cretácico Superior e Terciário de Portugal Central, a leste de Coimbra. PhD thesis, Univ. Coimbra.

Cunha, P.P., 2000. Paleoalterações e cimentações nos depósitos continentais terciários de Portugal central: importância na interpretação de processos antigos. Ciências da Terra (UNL) 14, 145-154.

Cunha, P.P., Almeida, N.A.C., Aubry, T., Martins, A., Murray, A.S., Buylaert, J.-P., Sohbati, R., Raposo, L., Rocha, L., 2012. Records of human occupation from Pleistocene river terrace and aeolian sediments in the Arneiro depression (Lower Tejo River, central eastern Portugal). Geomorphology 165-166, 7890, http://dx.doi.org/10.1016/j.geomorph.2012.02.017.

Cunha, P.P., Barbosa, B.P., Pena dos Reis, R., 1993. Synthesis of the Piacenzian onshore record between the Aveiro and Setúbal parallels (Western Portuguese margin). Ciências da Terra (UNL) 12, 35-43.

Cunha, P.P., Canilho, S., Pereira, D.I., Gouveia, J., Martins, A., 2009. O Monumento Natural das Portas de Ródão. Geonovas 22, 3-13.

Cunha, P.P., Lopes, F.C., Gomes, A., Pereira, D.I., Cabral, J., De Vicente, G., Martins, A., 2010. Os terraços do rio Douro como indicadores de desnivelamentos tectónicos e do soerguimento crustal (área do Pocinho, zona de falha da Vilariça). Resúmenes de la $1^{\text {a }}$ Reunión Ibérica sobre Tectónica Activa y Paleosismología, Sigüenza, España.

Cunha, P.P., Martins, A., 2004. Principais aspectos geomorfológicos de Portugal central, sua relação com o registo sedimentar e a importância do controlo tectónico. In: Araújo, M.A., Gomes, A. (Eds.), Geomorfologia do NW da Península Ibérica. Faculdade de Letras da Universidade do Porto, pp. 155-182.

Cunha, P.P., Martins, A., Daveau, S., Friend, P.F., 2005. Tectonic control of the Tejo river fluvial incision during the late Cenozoic, in Ródão - central Portugal (Atlantic Iberian border). Geomorphology 64, 271-298, http://dx.doi.org/ 10.1016/j.geomorph.2004.07.004.

Cunha, P.P., Martins, A., Huot, S., Murray, A., Raposo, L., 2008. Dating the Tejo river lower terraces in the Rodão area (Portugal) to assess the role of tectonics and uplift. Geomorphology 102, 43-54, http://dx.doi.org/10.1016/j.geomorph. 2007.05.019.

Cunha, P.P., Pena dos Reis, R., 1995. Cretaceous sedimentary and tectonic evolution of the northern sector of the Lusitanian Basin. Cretaceous Research 16, 155-170.

Cunha, P.P., Pereira, D.I., 2000. Evolução cenozóica da área de Longroiva-Vilariça (NE Portugal). Ciências da Terra (UNL) 14, 89-98.

Cunha, P.P., Pimentel, N.L., Pereira, D.I., 2000. Assinatura tectono-sedimentar do auge da compressão bética em Portugal - a descontinuidade sedimentar intraValesiano terminal. Ciências da Terra (UNL) 14, 61-72.

Daveau, S., Birot, P., Ribeiro, O., 1986. Les Bassins de Lousã et d' Arganil. Memórias do Centro de Estudos Geográficos, n. ${ }^{\circ}$ 8, Vol. I e II, Lisboa.

De Vicente, G., Cloetingh, S., Van Wees, J.D., Cunha, P.P., 2011. Tectonic classification of Cenozoic Iberian foreland basins. Tectonophysics 502, 38-61, http:// dx.doi.org/10.1016/j.tecto.2011.02.007.

De Vicente, G., Vegas, R., 2009. Large-scale distributed deformation controlled topography along the western Africa-Eurasia limit: tectonic constrains. Tectonophysics 474, 124-143, http://dx.doi.org/10.1016/j.tecto.2008.11.026.

De Vicente, G., Vegas, R., Muñoz Martín, A., Silva, P.G., Andriessen, P., Cloetingh, S., González, J.M., Van Wees, J.D., Álvarez, J., Carbó, A., Olaiz, A., 2007. Cenozoic thick-skinned deformation and topography evolution of the Spanish Central System. Global and Planetary Change 58, 335-381, http://dx.doi.org/10.1016/ j.gloplacha.2006.11.042.

Dias, G., Simões, P.P., Ferreira, N., Leterrier, J., 2002. Mantle and crustal sources in the genesis of Late-Hercynian Granitoids (NW Portugal): geochemical and Sr-Nd isotopic constraints. Gondwana Research 5, 287-305.

Ferreira, A.B., 1996. Geomorphology of Portugal: long-term evolution and tectonic setting. In: Ferreira, A.B., Vieira, G.T. (Eds.), Fifth European Intensive Course on Applied Geomorphology - Mediterranean and Urban Areas. Dep. Geografia. Univ. Lisboa, pp. 15-25.

Ferreira, A.B., 1993. As rañas em Portugal. Significado geomorfológico e estratigráfico. In: Ferreira, A.B., Carvalho, G.S., Senna-Martinez, J. (coord.), O Quaternário de Portugal. Balanço e Perspectivas. Edições Colibri, Lisboa, pp. 7-15.

Feuillet, T., Sourp, E., 2011. Geomorphological heritage of the Pyrenees National Park (France): assessment, clustering, and promotion of geomorphosites. Geoheritage 3, 151-162, http://dx.doi.org/10.1007/s12371-010-0020-y.

García-Cortés, A. (Ed.), 2008. Contextos geológicos españoles. Una aproximación al patrimonio geológico español de relevancia internacional. Instituto Geológico y Minero de España, Madrid.

García-Cortés, A., Rábano, I., Locutura, J., Bellido, F., Fernández-Gianotti, J., MartínSerrano, A., Quesada, C., Barnolas, A., Durán, J.J., 2001. First Spanish contribution to the Geosites Project: list of the geological frameworks established by consensus. Episodes 24, 79-92.

Gray, M., 2001. Geomorphological conservation and public policy in England: a geomorphological critique of English Nature's 'Natural Areas' approach. Earth Surface Processes and Landforms 26, 1009-1023, http://dx.doi.org/10.1002/esp.245.

Gray, M., 2013. Geodiversity: Valuing and Conserving Abiotic Nature, 2nd ed. Wiley-Blackwell.

Henriques, M.H., Pena dos Reis, R., Brilha, J., Mota, T.S., 2011. Geoconservation as an emerging geoscience. Geoheritage 3, 117-128, http://dx.doi.org/10.1007/ s12371-011-0039-8.

Martín-Serrano, A., 1988. El relieve de la región occidental zamorana. La evolución geomorfológica de un borde del Macizo Hespérico. Ed. Instituto de Estudios Zamoranos Florian de Ocampo, Zamora.
Martín-Serrano, A., 2004. El borde occidental de la cuenca del Duero. In: Araújo, M.A., Gomes, A. (Eds.), Geomorfologia do NW da Península Ibérica. Faculdade de Letras da Universidade do Porto, pp. 53-70.

Martins, A.A., Cunha, P.P., Huot, S., Murray, A.S., Buylaert, J.P., 2009. Geomorphological correlation of the tectonically displaced Tejo river terraces (GaviãoChamusca area, central Portugal), supported by luminescence dating. Quaternary International 199, 75-91, http://dx.doi.org/10.1016/j.quaint.2009.01.009.

Matte, P., 1986. Tectonics and plate tectonics model for the Variscan belt of Europe Tectonophysics 126, 329-332, http://dx.doi.org/10.1016/0040-1951(86) 90237-4.

Pais, J., Cunha, P.P., Pereira, D.I., Legoinha, P., Dias, R., Moura, D., Brum da Silveira, A. Kullberg, J.C., González-Delgado, J.A., 2012. The Paleogene and Neogene of Western Iberia (Portugal). A Cenozoic record in the European Atlantic domain. Springer Briefs in Earth Sciences, http://dx.doi.org/10.1007/978-3-642-224010.

Pereira, D.I., 1991. Evolução quaternária do rio Minho na região entre S. Pedro da Torre e Valença., Memórias e Notícias. Pub. Mus. Lab. Min. Geol. Univ. Coimbra 112, 327-345.

Pereira, D.I., 1999. Valorização de ocorrências singulares de rochas sedimentares a norte do Douro: o conglomerado de Cortes (Monção) e a Formação de Vale Álvaro (Bragança). I Seminário sobre Património Geológico, Comunicações. Inst. Geol. Min. Lisboa.

Pereira, D.I., 2010. Landscape and drainage evolution in Northern Portugal. Ciências Geológicas. Ciências Geológicas - Ensino e Investigação e sua História, Vol. I. Associação Portuguesa de Geólogos e Sociedade Geológica de Portugal, , pp. 491-500.

Pereira, D.I., Alves, M.I., Araújo, M.A., Cunha, P.P., 2000. Estratigrafia e interpretação paleogeográfica do Cenozóico continental do norte de Portugal. Ciências da Terra (UNL) 14, 73-84.

Pereira, D.I., Azevêdo, T., 1995. Evolução quaternária do graben da Vilariça (Trás-osMontes, NE Portugal). Cadernos do Laboratório Xeolóxico de Laxe 20, 123-137.

Pereira, D.I., Pereira, P., Alves, M.I., Brilha, J., 2004. Geomorphological frameworks in Portugal - a contribution for the characterization of the geological heritage. In: International Geological Congress, Florence, p. 32.

Pereira, D.I., Pereira, P., Alves, M.I., Brilha, J., 2006. Inventariação temática do património geomorfológico português. Publicações da Associação Portuguesa de Geomorfólogos 3, 155-159.

Pereira, D.I., Pereira, P., Brilha, J., Santos, L., 2013. Geodiversity assessment of Parana State (Brazil): an innovative approach. Environmental Management 52, 522 541, http://dx.doi.org/10.1007/s00267-013-0100-2.

Pereira, D.I., Pereira, P., Ferreira, N., 2010. Património Geológico e Geoconservação em Áreas Protegidas de Portugal Continental Ciências Geológicas - Ensino e Investigação e sua História, Associação Portuguesa de Geólogos e Sociedade Geológica de Portugal, vol. II. , pp. 451-463.

Pereira, P., Pereira, D., 2010. Methodological guidelines for geomorphosite assessment. Géomorphologie: Relief, Processus, Environnement 2, 215-222, http:// dx.doi.org/10.4000/geomorphologie.7942.

Pereira, P., Pereira, D., Alves, M., 2007. Geomorphosite assessment in Montesinho Natural Park (Portugal). Geographica Helvetica 62, 159-168., http://hdl.handle. net/1822/7436.

Pereira, P., Pereira, D., Brilha, J., 2012. Quantitative assessment of geosites with national and international relevance in Portugal: methodological procedures. Geologia dell'Ambiente, Supplemento al n. 3 14-15., http://hdl.handle.net $1822 / 20381$

Pralong, J.P., 2005. A method for assessing the tourist potential and use of geomorphological sites. Géomorphologie: Relief, Processus, Environnement 3 $189-196$.

Prosser, 2013. Our rich and varied geoconservation portfolio: the foundation for the future. Proceedings of the Geologists' Association 124, 568-580, http:// dx.doi.org/10.1016/j.pgeola.2012.06.001.

Prosser, C.D., Bridgland, D.R., Brown, E.J., Larwood, J.G., 2011. Geoconservation for science and society: challenges and opportunities. Proceedings of the Geologists' Association 122, 337-342, http://dx.doi.org/10.1016/j.pgeola.2011.01.007.

Reynard, E., Coratza, P., Regolini-Bissig, G. (Eds.), 2009. Geomorphosites. Pfeil, Munchen.

Reynard, E., Coratza, P., 2013. Scientific research on geomorphosites. A review of the activities of the IAG Working Group on Geomorphosites over the last twelve years. Geografia Fisica i Dinamica Quaternaria 36, 159-168.

Reynard, E., Fontana, G., Kozlik, L., Scapozza, C., 2007. A method for assessing the scientific and additional values of geomorphosites. Geographica Helvetica 62 $148-158$.

Ribeiro, A., Kullberg, M.C., Kullberg J.C., Manuppella, G., Phipps, S., 1990. A review of Alpine tectonics in Portugal: foreland detachment in basement and cover rocks. Tectonophysics 184, 357-366.

Ribeiro, O., 1949a. A Cova da Beira - Controvérsia de Geomorfologia. Comunicações dos Servicos Geológicos de Portugal 30, 23-41.

Ribeiro, O., 1949b. O Fosso do Médio Zêzere. Comunicações dos Serviços Geológicos de Portugal 30, 5-11

Ruban, D.A., 2010. Quantification of geodiversity and its loss. Proceedings of the Geologists' Association 121, 326-333, http://dx.doi.org/10.1016/j.pgeola.2010.07.002.

Santisteban, J., Schulte, L., 2007. Fluvial networks of the Iberian Peninsula: a chronological framework. Quaternary Science Reviews 26, 2738-2757, http://dx.doi.org/10.1016/j.quascirev.2006.12.019.

Serrano, E., González-Trueba, J.J., 2005. Assessment of geomorphosites in natural protected areas: the Picos de Europa National Park (Spain). Géomorphologie: Relief, Processus, Environnement 3, 197-208. 
Silva, J., Pereira, D.I., Aguiar, A.M., Rodrigues, C., 2013. Geodiversity assessment of the Xingu drainage basin. Journal of Maps 9, 1-9, http://dx.doi.org/10.1080/ 17445647.2013.775085.

Silva, J., Rodrigues, C., Pereira, D.I., 2015. Mapping and Analysis of Geodiversity Indices in the Xingu River Basin, Amazonia, Brazil, http://dx.doi.org/10.1007/ s12371-014-0134-8.

Vera, J.A., Ancochea, E., Barnolas, A., Bea, F., Calvo, J.P., Civis, J., De Vicente, G., Fernández-Gianotti, J., García-Cortés, A., Pérez Estaún, A., Pujalte, V., RodríguezFernández, L.R., Sopeña, A., Tejero, R., 2004. Chapter 1 - Introduction. In: Vera, J.A. (Ed.), Geología de España. SGE-IGME, Madrid.

Vieira, M., Poças, E., Pais, J., Pereira, D., 2011. Pliocene flora from S. Pedro da Torre deposits (Minho, NW Portugal). Geodiversitas 33, 71-85, http://dx.doi.org/ 10.5252/g2011n1a5.

Viveen, W., Braucher, R., Bourlès, D., Schoorl, J.M., Veldkamp, A., van Balen, R.T., Wallinga, J., Fernandez-Mosquera, D., Vidal-Romani, J.R., Sanjurjo-Sanchez, J., 2012. A 0.65 Ma chronology and incision rate assessment of the NW Iberian Miño River terraces based on $10 \mathrm{Be}$ and luminescence dating. Global and Planetary Change 94-95, 82-100, http://dx.doi.org/10.1016/j.gloplacha.2012.07.001.

Viveen, W., Schoorl, J.M., Veldkamp, A., Van Balen, R.T., Desprat, S., Vidal-Romani, J.R., 2013. Reconstructing the interacting effects of base level, climate, and tectonic uplift in the lower Miño River terrace record: a gradient modelling evaluation. Geomorphology 186, 96-118, http://dx.doi.org/10.1016/j.geomorph. 2012.12.026

Viveen, W., Van Balen, R.T., Schoorl, J.M., Veldkamp, A., Temme, A.J.A.M., VidalRomani, J.R., 2012. Assessment of recent tectonic activity on the NW Iberian Atlantic Margin by means of geomorphic indices and field studies of the Lower Miño River terraces. Tectonophysics 544-545, 13-30, http://dx.doi.org/ 10.1016/j.tecto.2012.03.029.

Wilson, R.C.L., Hiscott, R.N., Willis, M.G., Gradstein, F.M., 1989. The Lusitanian Basin of West-Central Portugal: Mesozoic and Tertiary Tectonic, Stratigraphic, and Subsidence History: Chapter 22: European-African MarginsIn: Memoir 46 (Extensional Tectonics and Stratigraphy of the North Atlantic Margins). , pp. 341-361.

Wimbledon, W.A., Andersen, S., Cleal, C.J., Cowie, J.W., Erikstad, L., Gonggrijp, G.P., Johansson, C.E., Karis, L.O., Suominen, V., 1999. Geological World Heritage: GEOSITES - a global comparative site inventory to enable prioritisation for conservation. Memorie Descrittive della Carta Geologica d'Italia 54, 45-60.

Zouros, N., 2007. Geomorphosite assessment and management in protected areas of Greece, Case study of the Lesvos island - coastal geomorphosites. Geographica Helvetica 62, 169-180. 